\title{
American Society - \\ Dream or Nightmare
}

In the last issue of American Studies in Scandinavia a change of date for our next NAAS conference was announced. The conference will take place on the 25th and 26th of June, 1971, and its theme will be United States in the 1870's. Roles and Realities. It will not be held in Denmark as was earlier announced but in Kungälv outside Gothenburg. NAAS will make the arrangements in cooperation with the Nordic Academy of Kungalv which has lately specialized in courses in the field of international relations.

The main theme of the conference will concern the role of the US in world politics as reflected against the domestic problems of US society. The main purpose is to try to discern the realities which constitute ohe US position as a world power »as a society in stagnation and revolt, as dream and nightmare reflected in the mirror of literature,.

The program of this conference is somewhat different and the setting of it will be less glamorous than that of the previous conferences, but we hope that it will be of the same quality. Professor K E Svendsen, special adviser to President Nyerere, will lecture about US and the Third World. Other domestic American problems will be treated by Professor Peter Rose, Smith College, and Professor Daniel Boorstin, Smithsonian Institute, Washington. A more detailed conference program will be published in the next issue. The last day for applications will be June 1, 1971.

In the first book compiled from a NAAS conference Amerika och Norden (America and the Nordic countries) Harald Elovson discussed the attitudes among liberals in Sweden towards the US up to 1820. In this issue of American Studies in Scandinavia Nils Runeby has treated the same theme for the period up to the 1860's. He has also broadened 
his investigation to include the attitudes towards emigration in various political quarters. Frederyka Kalinowska, who has eanlier specialized in the field of diplomatic history in Poland, is now carrying out research in Sweden. She shows us how differently contemporary historians laoked upon the American Revolution.

Two young scholars also contribute with short studies. Daniel Ogden discusses Richard Wright's classic narrative Native Son and Jessie Lokrantz presents an interesting finding about T S Eliot's use of Tarot cards in The Waste Land. We also publish a small report about Black I-listtory in Finland by Jeremy P Felt.

On several occassions NAAS bas discussed the 'realization of an area studies program which would include the US and Canada. In spite of the obvious difficulties in establishing interdisciplinary studies in the Scandinavian countries there is now reason to actualize those plans, and during the past term we have discussed a preliminary educational program in Uppsala. It is satisfactory to note that the interest in area studies program has increased. The bold American experiment with interdisciplinary studies in Green Bay, Wisc., has aroused positive interest among university people in Sweden. At present when parochialism is strengthened rather than weakened there is every reason to consider new forms of educational planning and here American Studies offers a convenient initiative. At the same time we must realize that it is as urgent to support the study of other continents of which we know even less rhan about the US.

Sune Äkerman 